\title{
Direct Evidence that Decreased Serum Opsonization of Streptococcus pneumoniae Via the Alternative Complement Pathway in Sickle Cell Disease is Related to Antibody Deficiency
}

Ann B. Bjornson and Jeffrey S. Lobel

Division of Immunology, James N. Gamble Institute of Medical Research, Cincinnati, Ohio 45219; Division of Hematology-Oncology, Children's Hospital Research Foundation; and the Cincinnati Comprehensive Sickle Cell Center, Cincinnati, Ohio 45229

\begin{abstract}
Two approaches were used to demonstrate that reduction in serum opsonization of Streptococcus pneumoniae via the alternative complement pathway in children with sickle cell disease is related to a deficiency of antibodies to pneumococcal capsular polysaccharide. First, opsonization of $S$. pneumoniae mediated by the alternative pathway in patients' sera was restored to normal by addition of the purified IgG or IgM fraction of goat antiserum to capsular polysaccharide of the homologous serotype. Secondly, IgG antibody titers to capsular polysaccharide in patients' sera correlated significantly with alternative pathwaymediated opsonization; the correlation between titers of IgM anticapsular antibodies and opsonization approached statistical significance. The sum of the IgG and IgM anticapsular antibody titers correlated most significantly with opsonization. Our results suggest that reduction in alternative pathway-mediated opsonization in sera from children with sickle cell disease is related to low levels of both IgG and IgM anticapsular antibodies.
\end{abstract}

\section{Introduction}

Children with sickle cell disease are at high risk of development of pneumococcal septicemia and meningitis (1-3). Splenic hypofunction is a major factor contributing to the increased susceptibility to pneumococcal infection (4-6). A second, less well characterized alteration of host defense occurring in a subpopulation of children and adults with sickle cell disease is reduction in serum opsonization of Streptococcus pneumoniae (7-14). Initial studies attempting to characterize this alteration examined the relationship between serum opsonization of $S$. pneumoniae and various functional measurements of complement, i.e., total hemolytic complement and C3 conversion by activators of the alternative complement pathway (zymosan, inulin, and cobra venon factor) (7-10). Total hemolytic complement was found to be below normal in certain sera, but not consistently in opsonically deficient sera (7-10). Johnston et al. demonstrated that C3 conversion by zymosan was reduced in these sera (8). How-

Address requests for reprints to Dr. Bjornson, Division of Immunology, James N. Gamble Institute of Medical Research, 2141 Auburn Avenue, Cincinnati, OH 45219. Dr. Lobel's present address is Department of Pediatric Subspecialties, Geisinger Medical Center, Danville, PA 17822. 1986.

Received for publication 3 March 1986 and in revised form 27 October

J. Clin. Invest.

(c) The American Society for Clinical Investigation, Inc.

$0021-9738 / 87 / 02 / 0388 / 11 \quad \$ 1.00$

Volume 79, February 1987, 388-398 ever, studies from our laboratory using inulin and cobra venom factor as the complement activators demonstrated normal C3 conversion in opsonically deficient sera $(9,10)$.

Subsequent studies from our laboratory have attempted to resolve the divergent results. Opsonization of $S$. pneumoniae selectively mediated by the alternative and classical pathways and concomitant deposition of $\mathrm{C} 3$ fragments on the bacterial surface were measured in sera from children with sickle cell disease and normal siblings of similar age (14). Both alternative and classical pathway-mediated opsonization were found to be significantly reduced in a subset of children with sickle cell disease. Reduction in classical pathway-mediated opsonization was related to a quantitative decrease in $\mathrm{C} 3$ deposition on the pneumococci; however, total hemolytic complement reflecting the intrinsic functional activity of the classical pathway was normal in the sera. Reduction in alternative pathway-mediated opsonization was associated with normal C3 deposition. These observations suggested that opsonization might be reduced by a deficiency of auxiliary serum factors required for classical pathway activation, such as antibodies. An antibody deficiency might also explain the reduction in alternative pathway-mediated opsonization, since antibodies although not required for alternative pathway activation act synergistically with surface-bound C3 fragments to enhance phagocytosis $(15,16)$. The findings of Johnston et al. (8) might also be related to an antibody deficiency, since opsonization was normalized in their study when the pneumococci were presensitized with a high concentration of antipneumococcal antibodies before incubation with patient's serum and it is now recognized that $\mathbf{C} 3$ conversion by zymosan and other alternative pathway activators is influenced by antibodies (17). Additional support for the concept that antibodies may play a role in the reduction in opsonization in sickle cell disease has been derived from a preliminary study from our laboratory demonstrating restoration of opsonic activity in patients' sera by IgG fractionated from normal human serum (18).

The present investigation extends the observations described above by providing direct evidence that reduction in serum opsonization via the alternative complement pathway in children with sickle cell disease is related to a deficiency of antibodies to pneumococcal capsular polysaccharide. Two experimental approaches were used. First, the ability of purified IgG and IgM fractions of goat antiserum to pneumococcal capsular polysaccharide to restore alternative pathway-mediated opsonization of the homologous pneumococcal serotype in patients' sera was determined. Secondly, IgG and IgM antibody titers to the capsular polysaccharide were compared in sera from patients and controls, and correlations between these titers and alternative pathway-mediated opsonization in patients' sera were assessed. A preliminary investigation of the mode of enhancement of alternative pathway-mediated opsonization by anticapsular IgG and IgM was also undertaken. 


\section{Methods}

Patients and controls. Patients with sickle cell disease had hemoglobin SS, SC, or S- $\beta^{+}$-thalassemia. Healthy Black children of similar age served as controls. These children were hematologically normal or had $\beta$-thalassemia trait or $\delta, \beta$-thalassemia trait. All patients with sickle cell disease had been vaccinated with the 14-valent pneumococcal polysaccharide vaccine; none had received the 23-valent pneumococcal polysaccharide vaccine containing serotype $10 \mathrm{~A}$ capsular polysaccharide. Informed consent of all subjects was obtained and the protocol for this study was approved by the institutional review boards of the James N. Gamble Institute of Medical Research and the Cincinnati Children's Hospital Medical Center.

Collection and handling of serum specimens. Whole blood was drawn in glass tubes, allowed to clot at room temperature, and then stored at $4^{\circ} \mathrm{C}$ for up to $4 \mathrm{~h}$. The tubes were centrifuged at $750 \mathrm{~g}$ for $10 \mathrm{~min}$ at $4^{\circ} \mathrm{C}$. The sera were removed and stored in small aliquots at $-70^{\circ} \mathrm{C}$. Sera were frozen and thawed at most two times. All patients were asymptomatic at the time of blood collection except one with an acute cerebral vascular accident.

Preparation of antiserum to pneumococcal capsular polysaccharide. Purified serotype 10A pneumococcal capsular polysaccharide prepared by Merck Sharp \& Dohme (West Point, PA) was obtained from the American Type Culture Collection (Rockville, MD); these preparations have been previously shown to contain minimal contaminating C-polysaccharide $(19,20)$. Goats were injected subcutaneously at four separate sites with $50 \mu \mathrm{g}$ of purified capsular polysaccharide incorporated into Freund's complete adjuvant (Difco Laboratories, Detroit, MI). The injections were performed one time weekly for $6 \mathrm{wk}$. The goats were bled $7 \mathrm{~d}$ after the last injection. The antiserum formed a single precipitin line in double immunodiffusion with serotype $10 \mathrm{~A}$ capsular polysaccharide, whereas reactivity was not observed with goat serum obtained prior to immunization.

Fractionation of anticapsular IgG and IgM. $100 \mathrm{ml}$ of goat antiserum to serotype $10 \mathrm{~A}$ capsular polysaccharide were first fractionated on a 5 $\times 80 \mathrm{~cm}$ column of Sephacryl S-300 (Pharmacia Fine Chemicals, Piscataway, NJ) equilibrated with $0.01 \mathrm{M}$ phosphate-buffered saline (PBS), $\mathrm{pH}$ 7.0. IgM containing fractions were further purified by polyethylene glycol precipitation, affinity chromatography on anti-goat IgM Sepharose 4B, and subsequent chromatography on Sephacryl S-300 (21). The immunoadsorbent was prepared by coupling the IgG fraction of antiserum to goat IgM (gamma chain-specific; Pel-Freez Biologicals, Rogers, AR) to Sepharose 4B (Pharmacia Fine Chemicals) by cyanogen bromide activation (22); the IgG fraction of antiserum to IgM was prepared by precipitation with ammonium sulfate (23). IgG containing fractions from the Sephacryl column were further purified by ammonium sulfate precipitation followed by chromatography on DEAE-Sephacel (Pharmacia Fine Chemicals) (24). Immunoglobulin containing fractions were identified by double immunodiffusion using antiserum to goat IgG ( $\mathrm{Fc}$ fragment specific; Pel-Freez Biologicals) or goat IgM (gamma chain specific). Final preparations were dialyzed at $4^{\circ} \mathrm{C}$ against $\mathrm{PBS}, \mathrm{pH} 7.0$, and frozen in small aliquots at $-70^{\circ} \mathrm{C}$. The immunoglobulin preparations were centrifuged at $10,000 \mathrm{~g}$ for $5 \mathrm{~min}$ at $4^{\circ} \mathrm{C}$ to remove possible aggregates prior to use in the experiments.

Purification of C3. C3 was prepared by precipitation of human plasma with polyethylene glycol and successive chromatography on L-lysineSepharose 4B, DEAE-Sephacel, and Sepharose CL-6B (25). Trace contaminants were removed by chromatography on 10-20-ml columns of anti-IgG Sepharose 4B, anti-IgA Sepharose 4B, and anti-C5 Sepharose 4B equilibrated with isotonic veronal buffered saline (VBS), ${ }^{1} \mathrm{pH} 7.4$. These columns were prepared by coupling the IgG fraction of respective antiserum to Sepharose 4B by cyanogen bromide activation (22); IgG

1. Abbreviations used in this paper: cfu, colony forming units; HBG, Hanks' balanced salt solution containing $0.1 \%$ gelatin; VBS, isotonic veronal buffered saline, $\mathrm{pH}$ 7.4. fractions of the antisera were prepared by ammonium sulfate precipitation (23). Antiserum to human IgG was provided by Dr. Robert Schreiber, Washington University School of Medicine, St. Louis, MO, and antisera to human IgA and C5 were obtained from Behring Diagnostics, La Jolla, CA. L-Lysine-Sepharose 4B was prepared by coupling L-lysine to Sepharose $4 \mathrm{~B}$ by cyanogen bromide activation (22). Final C3 preparations were dialyzed overnight at $4^{\circ} \mathrm{C}$ against VBS and stored in small aliquots at $-70^{\circ} \mathrm{C}$. As reported previously (14), these preparations were highly purified as assessed by sodium dodecyl sulfate (SDS) polyacrylamide gel electrophoresis and double immunodiffusion using a battery of antisera to human complement components, immunoglobulins, and other serum proteins.

Measurement of protein. Protein in purified preparations was quantitated by the method of Lowry et al. (26).

SDS polyacrylamide gel electrophoresis. SDS polyacrylamide gel electrophoresis was performed by the method of Laemmli (27) in 10\% polyacrylamide slab gels. Immunoglobulins were treated with $8.7 \mathrm{M}$ urea and $0.02 \mathrm{M}$ iodoacetamide and heated for $45 \mathrm{~min}$ at $37^{\circ} \mathrm{C}$ before application. Samples were reduced by inclusion of $0.1 \mathrm{M}$ dithiothreitol. The amount of protein applied to the gels was $5 \mu \mathrm{g}$. Molecular weight standards from Bethesda Research Laboratories, Inc. (Gaithersburg, MD) were run simultaneously. Gels were fixed overnight in an aqueous solution of $25 \%$ propanol and $10 \%$ glacial acetic acid. Gels were silver stained using reagents from Bio-Rad Laboratories (Richmond, CA) and the manufacturer's directions.

Double immunodiffusion. Double immunodiffusion was carried out at room temperature for $18 \mathrm{~h}$ in $0.6 \%$ agarose in PBS, $\mathrm{pH} 7.0$. Antisera to goat IgM (gamma chain-specific), goat IgG (Fc-specific), and whole goat serum (Pel-Freez Biologicals) were used.

Growth of the bacteria. Serotype 10A S. pneumoniae was a clinical isolate used in our previous studies $(9,10,14,18)$. Subtyping was performed by Dr. Richard R. Facklam, Centers for Disease Control, Altanta, GA. The bacterial strain was subjected to mouse passage and then maintained in sterile skim milk at $-70^{\circ} \mathrm{C}$. S. pneumoniae $\mathrm{R} 36 \mathrm{a}$ was obtained from the American Type Culture Collection and was also stored in skim milk in frozen form. Cultures were thawed and inoculated into Todd Hewitt broth (Difco Laboratories, Detroit, MI). For preparation of radiolabeled bacteria, broth was supplemented with $10 \mu \mathrm{Ci} / \mathrm{ml}$ of $\left[{ }^{3} \mathrm{H}\right] \mathrm{L}$ amino acid mixture (New England Nuclear, Boston, MA). Cultures were incubated for $4 \mathrm{~h}$ at $37^{\circ} \mathrm{C}$ in $5 \% \mathrm{CO}_{2}$. Bacteria were washed and resuspended in PBS, pH 7.4.

Preparation of polymorphonuclear leukocytes. Polymorphonuclear leukocytes from normal adult donors were isolated by centrifugation of heparinized blood on Hypaque-Ficoll (28). Contaminating erythrocytes were removed by hypotonic lysis with $0.2 \%$ sodium chloride; isotonicity was restored by addition of an equal volume of $1.6 \%$ sodium chloride. Leukocytes were washed and resuspended in Hanks' balanced salt solution (M. A. Bioproducts, Walkersville, MD) containing $0.1 \%$ gelatin (HBG, Difco Laboratories). Suspensions contained $98 \%$ or more polymorphonuclear leukocytes.

Opsonization of bacteria. Radiolabeled serotype 10A S. pneumoniae $\left(5.0 \times 10^{7}\right.$ colony forming units $\left.(\mathrm{cfu}) / \mathrm{ml}\right), 50 \%$ serum (vol/vol), $0.01 \mathrm{M}$ ethylene glycol tetraacetic acid and $0.01 \mathrm{M}$ magnesium chloride $(\mathrm{Mg}$ EGTA), purified immunoglobulin preparations (12.5-50 $\mu \mathrm{g}$ ), and Hanks' balanced salt solution in a total volume of $250 \mu \mathrm{l}$ were incubated for 15 min at $37^{\circ} \mathrm{C}$. Hanks' balanced salt solution was substituted for the serum or immunoglobulin preparations in the controls. In preliminary experiments, serum was heated for $30 \mathrm{~min}$ at $56^{\circ} \mathrm{C}$ or treated with $0.01 \mathrm{M}$ ethylenediaminetetraacetic acid (EDTA). After opsonization, the bacteria were washed once with $1.5 \mathrm{ml}$ of HBG and resuspended to the original concentration in HBG.

Measurement of total hemolytic complement. Total hemolytic complement in normal human serum treated with MgEGTA was titrated by the method of Mayer (29).

Measurement of bacterial uptake and killing. Opsonized bacteria and normal polymorphonuclear leukocytes at final concentrations of $2.5 \times 10^{7}$ cells or cfu/ml were rotated for $8 \mathrm{~min}$ at $37^{\circ} \mathrm{C}$. In some experiments, the leukocytes were pretreated for $10 \mathrm{~min}$ at room temperature with 10 
$\mu \mathrm{g} / \mathrm{ml}$ of cytochalasin B to inhibit ingestion before mixture with opsonized bacteria (30). Measurements of bacterial uptake and killing were performed as previously described (14). For measurement of bacterial uptake, aliquots were centrifuged at $190 \mathrm{~g}$ for $5 \mathrm{~min}$ at $4^{\circ} \mathrm{C}$. The leukocytes were washed three times with cold HBG. Leukocyte pellets and samples removed before incubation for measurement of input counts per minute were solubilized and counted. For measurement of killing, aliquots removed before and after incubation were serially diluted in distilled water and plated on blood agar. Percent uptake, reflecting both adherent and ingested bacteria, was calculated by dividing the counts per minute in the leukocyte pellets by the input counts per minute and multiplying by 100. Percent killing was calculated by the formula $(a-b) / a \times 100$, where $a$ and $b$ were equal to surviving $\mathrm{cfu} / \mathrm{ml}$ before and after incubation, respectively. The 8-min incubation time was used, because it was the minimum required for maximal uptake and killing of bacteria opsonized with normal sera. In some experiments, purified immunoglobulin preparations were added together with the leukocytes after opsonization of the bacteria with serum.

Adsorption of anticapsular IgG and IgM with bacteria. Purified IgG and IgM fractions of goat antiserum to capsular polysaccharide (1 mg/ $\mathrm{ml}$ ) were adsorbed for $30 \mathrm{~min}$ at $37^{\circ} \mathrm{C}$ with $20 \%$ packed volume of serotype 10A $S$. pneumoniae or $S$. pneumoniae R36a. After adsorption, bacteria were pelleted by centrifugation, and the supernatants were removed.

Electron microscopy. Bacteria were incubated with serum and anticapsular IgG or serum alone using the conditions described for opsonization, except the bacteria were not radiolabeled. After washing, the bacteria were incubated with polymorphonuclear leukocytes under the conditions used for measurement of bacterial uptake. The leukocytes were washed three times with HBG, fixed in $2.5 \%$ glutaraldehyde in 0.07 $M$ sodium cacodylate buffer for $4 \mathrm{~h}$ at $4^{\circ} \mathrm{C}$, and dehydrated in graded alcohol solutions and propylene oxide. The samples were embedded in Spurr medium, thin-sectioned with an ultramicrotome, and stained with uranyl acetate and lead citrate. The preparations were examined and photographed using a Zeiss 9S electron microscope (Carl Zeiss, Inc., Thornwood, NY). These studies were performed by Dr. Muhammad Ashraf, University of Cincinnati College of Medicine, Cincinnati, $\mathrm{OH}$.

Radioiodination of proteins. Purified proteins were radioiodinated by the lactoperoxidase method using Enzymobeads from Bio-Rad Laboratories and the manufacturer's general directions. For radioiodination of C3, purified C3 $(100 \mu \mathrm{g}), 300 \mu \mathrm{Ci}$ of sodium ${ }^{125} \mathrm{I}$ (Amersham Corp., Arlington Heights, IL), $25 \mu \mathrm{l}$ of Enzymobead reagent, $20 \mu \mathrm{l}$ of $1 \% \beta$-Dglucose, and $40 \mu \mathrm{l}$ of $0.2 \mathrm{M}$ sodium phosphate buffer, $\mathrm{pH} 7.2$, in a total volume of $100 \mu \mathrm{l}$ were incubated for $30 \mathrm{~min}$ on ice. For radioiodination of anticapsular IgG and IgM, $500 \mu \mathrm{g}$ of immunoglobulin preparation and $250 \mu \mathrm{Ci}$ of sodium ${ }^{125} \mathrm{I}$ were used. Free iodine was removed by chromatography on Sephadex G-25. Specific activity of the radioiodinated C3 preparations ranged from 0.47 to $1.73 \mu \mathrm{Ci} / \mu \mathrm{g}$. Specific activities of radioiodinated anticapsular $\mathrm{IgG}$ and $\mathrm{IgM}$ were 0.19 and $0.03 \mu \mathrm{Ci} / \mu \mathrm{g}$, respectively. Titration of $\mathrm{C} 3$ hemolytic activity (31) showed that hemolytic activity in radioiodinated $\mathrm{C} 3$ was equivalent to that in nonlabeled $\mathrm{C} 3$ on a weight basis, indicating that no loss of functional activity resulted from the iodination procedure. Radioiodinated and nonlabeled anticapsular IgG and IgM also had similar functional activity as assessed by comparing the ability of these preparations to restore opsonization in patients' sera.

Quantitation of $C 3$ deposition. C3 deposition on serotype 10A $S$. pneumoniae was measured by radioassay as described previously (14). Briefly, serum was supplemented with radioiodinated $C 3$, centrifuged to remove possible aggregates, and incubated with the bacteria and purified immunoglobulin preparations under the conditions used for opsonization. Controls contained $0.01 \mathrm{M}$ EDTA to inhibit complement activation. After incubation for $15 \mathrm{~min}$ at $37^{\circ} \mathrm{C}$, samples were removed for measurement of bacterial-bound and total radioactivity. The percent of $\mathrm{C3}$ binding to the bacteria was calculated after subtraction of control values. Micrograms of bound C3 were calculated by multiplying the percent of binding by the $\mu \mathrm{g}$ of $\mathrm{C} 3$ in the samples. The concentration of $\mathrm{C} 3$ in each serum was determined by radial immunodiffusion and $\mathrm{C} 3$ molecules bound per cfu were calculated by the formula [ $\mu \mathrm{g}$ bound $\left.\mathrm{C} 3 \times 10^{-6}\right)$ / $\left.180,000 \times\left(6.023 \times 10^{23}\right)\right] / 3.75 \times 10^{6}$.

Measurement of binding of anticapsular IgG and IgM to bacteria. Serotype 10A S. pneumoniae or S. pneumoniae R36a $\left(5.0 \times 10^{6} \mathrm{cfu}\right)$ were incubated for $15 \mathrm{~min}$ at $37^{\circ} \mathrm{C}$ with purified radioiodinated anticapsular IgG or IgM (3.25-30 $\mu \mathrm{g})$ in a total volume of $100 \mu$ l. Reaction mixtures were prepared in duplicate. After incubation, 75- $\mu$ l samples were centrifuged through $300 \mu \mathrm{l}$ of $20 \%$ sucrose, and bacterial-bound and total radioactivity were measured. Results were expressed as immunoglobulin molecules bound per cfu and were calculated by the formula [ $\left(\mu \mathrm{g}\right.$ bound immunoglobulin $\left.\times 10^{-6}\right) / 150,000(\mathrm{IgG})$ or 900,000 $\left.(\mathrm{IgM}) \times\left(6.023 \times 10^{23}\right)\right] / 3.75 \times 10^{6}$

Measurement of antibody titers to pneumococcal capsular polysaccharide. Total IgG and IgM antibody titers to serotype 10A capsular polysaccharide were measured by the enzyme-linked immunosorbent assay (ELISA) using a minor modification of the method of Barrett et al. (32). Purified serotype 10A capsular polysaccharide obtained from the American Type Culture Collection was coupled to poly-L-lysine by the method of Gray (33). After coupling, the polysaccharide was dialyzed overnight at $4^{\circ} \mathrm{C}$ against PBS, pH 7.4, and stored at $4^{\circ} \mathrm{C}$. For coating wells, $100 \mu$ l of polysaccharide diluted to $8 \mu \mathrm{g} / \mathrm{ml}$ in $0.25 \mathrm{M}$ sodium bicarbonate/carbonate buffer, $\mathrm{pH} 9.5$, was added to the inner wells of microtiter plates (NUNC Immuno-1; Gibco Laboratories, Grand Island, $\mathrm{NY}$ ), and the plates were incubated overnight at $4^{\circ} \mathrm{C}$. Unbound polysaccharide was removed by three washes with distilled water followed by a 10-min soak in $0.15 \mathrm{M}$ phosphate buffer, $\mathrm{pH} 7.4$, containing 0.5 $\mathrm{M} \mathrm{NaCl}$ and $0.05 \%$ Tween 20 (PBS-Tween). Twofold dilutions (1:5-1: 2560) of the test sera and reference serum from an adult donor were prepared in PBS-Tween, and $100 \mu \mathrm{l}$ was added in duplicate to the wells. Control wells to which no serum was added were included in quadruplicate on each plate. The plates were incubated for $2 \mathrm{~h}$ at room temperature and then washed extensively as described above. $100 \mu \mathrm{l}$ of alkaline phosphatase-conjugated goat anti-human IgG or IgM (Sigma Chemical Co., St. Louis, MO) diluted 1:1,000 in PBS-tween was added to the wells. The plates were incubated for $2 \mathrm{~h}$ at room temperature and then washed extensively as above. $100 \mu$ l of $p$-nitrophenyl phosphate (Sigma Chemical Co.) at a concentration of $1 \mathrm{mg} / \mathrm{ml}$ in $0.05 \mathrm{M}$ sodium bicarbonate/carbonate buffer, $\mathrm{pH} 9.8$, containing $0.001 \mathrm{M}$ magnesium chloride was added to the wells. The plates were incubated at room temperature for $15 \mathrm{~min}(\mathrm{IgG})$ or $20 \mathrm{~min}$ (IgM), and the reaction was stopped by addition of $50 \mu \mathrm{l}$ of $3 \mathrm{~N} \mathrm{NaOH}$. The absorbance at $405 \mathrm{~nm}$ was measured using an ELISA reader (Litton Bionetics Inc., Charleston, SC). Antibody titers were calculated from plots of absorbance versus logarithm of the serum dilution. The titer was defined as the serum dilution which yielded 0.4 absorbance units. Determinations were carried out simultaneously in plates lacking antigen. Absorbance was negligible, comparable to that in controls lacking serum.

Reference serum was included in order to evaluate the daily variation in results. In four separate experiments with different antigen preparations, IgG antibody titers in the reference serum ranged from 572 to 837 with a mean of 694 , and IgM antibody titers ranged from 53 to 68 with a mean of 62. Determinations using four separate plates coated with the same antigen preparation gave a range of 620 to 700 with a mean of 655 for IgG antibody titers and 45 to 62 with a mean of 56 for IgM antibody titers.

The method described above was modified for measurement of IgG subclass-specific antibody titers to serotype $10 \mathrm{~A}$ capsular polysaccharide in patients' sera. After incubating the polysaccharide coated wells with test sera and then washing, $100 \mu l$ of an appropriate dilution of monoclonal antibody to the respective human IgG subclass in PBStween (1:250 for anti-IgG2 and 1:500 for anti-IgG1, anti-IgG3, and antiIgG4) was added to the wells, and the plates were incubated for $2 \mathrm{~h}$ at room temperature. The monoclonal antibodies to IgG subclasses were obtained from Unipath Limited (Bedford, UK) in ascites; clone numbers were NL16 (anti-IgG1), G0M2 (anti-IgG2), ZG4 (anti-IgG3), and RJ4 (anti-IgG4). After washing the plates three times with PBS-tween, 100 $\mu l$ of a 1:500 dilution of alkaline phosphatase conjugated anti-mouse IgG (Sigma Chemical Co.) in PBS-Tween was added to the wells, and 
the plates were incubated for $2 \mathrm{~h}$ at room temperature. After additional washing, substrate was added, and the reactions were stopped after 15 min of incubation at room temperature. Absorbance was read, and titers were calculated as described above. Controls without antigen or monoclonal antibody were included in all experiments. Absorbance readings in these controls were negligible.

The specificity and sensitivity of the assays were determined using reference preparations of human IgG subclass proteins obtained from the World Health Organization, Berne, Switzerland. Two preparations of each subclass, one each with lambda and kappa light chains, were used. For determinations of specificity, wells were coated at $4^{\circ} \mathrm{C}$ overnight with $100 \mu \mathrm{l}$ of the IgG subclass proteins $(1 \mu \mathrm{g} / \mathrm{ml})$ in $0.25 \mathrm{M}$ sodium bicarbonate/carbonate buffer, $\mathrm{pH}$ 9.5. After washing the plates three times with PBS-Tween, monoclonal antibodies in dilutions used in the experiments described above were added to the wells and incubated for $2 \mathrm{~h}$ at room temperature. The rest of the procedure was carried out as described above. For determination of the sensitivity of the assays, wells were coated with fivefold dilutions of the IgG subclass proteins at concentrations ranging from 1 to $0.01 \mu \mathrm{g} / \mathrm{ml}$. Monoclonal antibody to the homologous subclass at the dilution used above was then added followed by anti-mouse IgG.

Statistical analysis. Differences between antibody titers were determined by the Wilcoxon rank sum test (34). Correlations were assessed by Spearman rank-order correlation (34).

\section{Results}

Purity of anticapsular IgG and IgM. The IgG and IgM fractions of antiserum to pneumococcal capsular polysaccharide used in our experiments were highly purified as assessed by SDS polyacrylamide gel electrophoresis (Fig. 1). The immunoglobulin preparations formed a single precipitin line in double immunodiffusion with antiserum to whole goat serum and reacted strongly with antiserum to the homologous heavy chain of goat immunoglobulin. Reactivity was not demonstrated with antiserum to the heterologous heavy chain, indicating that the IgG and IgM preparations were devoid of cross contamination.

Requirement for complement for opsonization. Preliminary experiments demonstrated that treatment of normal human serum with $0.01 \mathrm{M}$ EDTA or by heating for $30 \mathrm{~min}$ at $56^{\circ} \mathrm{C}$ ablated uptake and killing of the pneumococcal test organism (serotype 10A) by polymorphonuclear leukocytes, indicating that complement was essential for opsonization. Total hemolytic complement was undetectable in serum treated with MgEGTA, indicating that the chelation conditions used during opsonization effectively blocked the classical complement pathway.

Enhancement of alternative pathway-mediated opsonization by anticapsular IgG and IgM. 10 patients with hemoglobin SS ranging in age from 2 to $18 \mathrm{yr}$ were used in this part of our investigation. Sera from these patients had been previously shown to have reduced alternative pathway-mediated opsonic activity for serotype 10A $S$. pneumoniae as compared with controls of similar age (14). Reduction in opsonic activity was manifest by bacterial uptake by normal polymorphonuclear leukocytes in the low normal or abnormal range and markedly reduced killing by the leukocytes. Supplementation of patients' sera with purified anticapsular IgG or IgM restored bacterial uptake and killing to normal or supranormal levels. Representative results obtained with sera from four patients are shown in Fig. 2. The trend of results was similar using sera from the other six patients. Using these sera without added immunoglobulin, uptake and killing (mean $\pm 1 \mathrm{SD}$ ) were $58 \pm 10 \%$ and $17 \pm 17 \%$, respectively. Addition of $50 \mu \mathrm{g}$ of anticapsular IgG to these sera increased uptake and killing to $81 \pm 12 \%$ and $86 \pm 2 \%$, respectively; anticapsular IgM at the same concentration increased uptake and killing to $82 \pm 17 \%$ and $72 \pm 13 \%$, respectively. The effect of the immunoglobulin preparations on the opsonic activity of a pool of normal serum was also determined. Uptake and killing (mean \pm 1 SD) of pneumococci opsonized with normal serum alone were $75 \pm 1 \%$ and $64 \pm 1 \%$, respectively. Anticapsular IgG (25 $\mu \mathrm{g})$ increased uptake and killing to $86 \pm 5 \%$ and $75 \pm 5 \%$, respectively; anticapsular IgM at the same concentration increased uptake and killing to $86 \pm 13 \%$ and $76 \pm 1 \%$, respectively. Increasing the concentrations of the immunoglobulin preparations to $50 \mu \mathrm{g}$ further increased killing to $80 \pm 1 \%$ (IgG) and $82 \pm 5 \%$ (IgM); up-

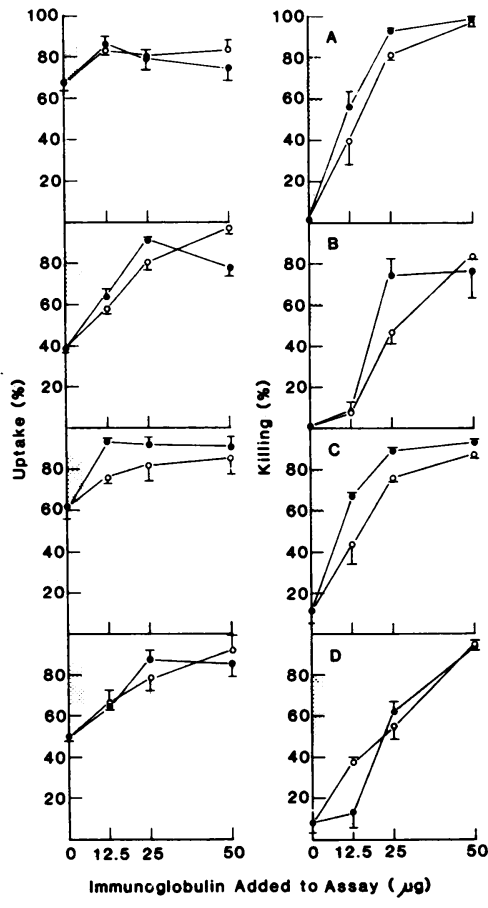

Figure 2. Uptake and killing by normal polymorphonuclear leukocytes of pneumococci opsonized with patients' sera supplemented with increasing concentrations of anticapsular IgG (closed circle) or IgM (open circle). $(A-D)$ show the data obtained with sera from patients 1-4. These data are expressed as mean \pm SEM of 2 to 14 determinations. Uptake and killing (mean $\pm 1 \mathrm{SD}$ ) using sera from 14 control subjects are shown in the shaded areas. These sera were not supplemented with purified immunoglobulins. gel electrophoresis of anticapsular IgG and IgM under reducing conditions. The bands correspond to heavy and light chains of IgG (left lane) and IgM (right lane). The gel was silver stained to increase sensitivity. 

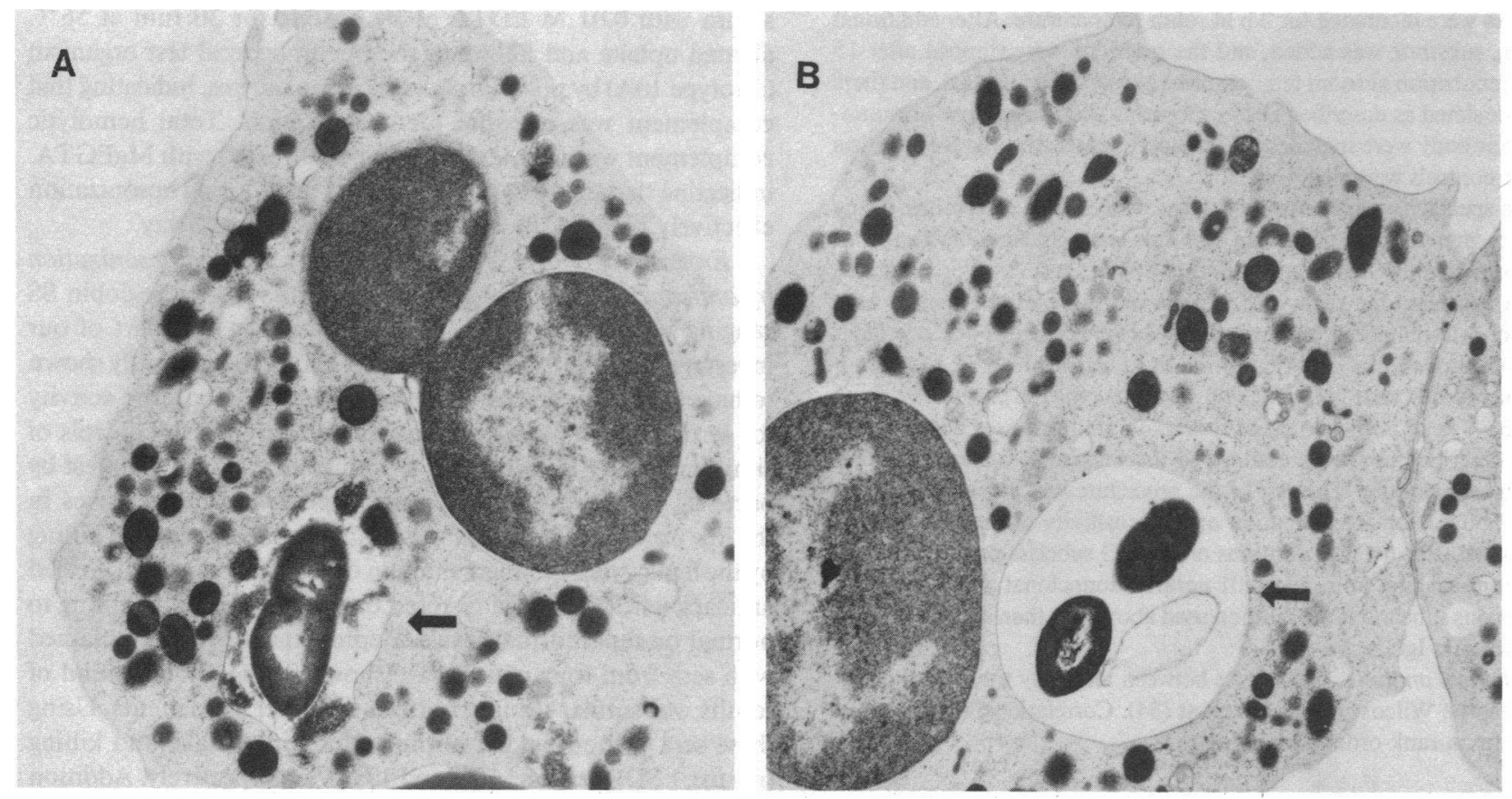

Figure 3. Electron micrographs showing ingestion by normal polymorphonuclear leukocytes of pneumococci opsonized with patient's serum in the presence $(B)$ and absence $(A)$ of anticapsular IgG. The ingested bacteria are contained within phagocytic vacuoles (arrows). Magnifications are $3,300(B)$ and $16,300(A)$.

take was not further increased. Anticapsular IgG and IgM (12.5$50 \mu \mathrm{g}$ ) promoted $<15 \%$ uptake and killing in the absence of serum. These results indicated that the immunoglobulin preparations enhanced opsonization in both patients' and normal sera by acting synergistically with complement.

Experiments were performed to determine why patients' sera were capable of facilitating bacterial uptake by polymorphonuclear leukocytes but minimal killing in the absence of added immunoglobulin. Leukocytes were treated with cytochalasin B under conditions known to inhibit ingestion, and uptake of bacteria opsonized with patients' sera and pooled normal human serum was compared. Uptake of bacteria opsonized with patients' sera was unaffected by treatment of the leukocytes with cytochalasin B (data not shown), whereas the cytochalasin B treatment reduced uptake of bacteria opsonized with normal serum from $85 \%$ to $52 \%$. These results suggested that patients' sera facilitated adherence of the pneumococci to polymorphonuclear leukocytes but were unable to promote the internalization phase of phagocytosis necessary for killing.

Additional support for this concept was derived from electron microscopic studies. In these studies, bacteria were opsonized with patient's serum in the presence or absence of $50 \mu \mathrm{g}$ of anticapsular IgG. The opsonized bacteria were incubated with normal polymorphonuclear leukocytes, and nonleukocyte-associated bacteria were removed using the conditions employed in the uptake assay. When the bacteria were opsonized with patient's serum in the absence of IgG, few polymorphonuclear leukocytes contained ingested bacteria. When present, ingested bacteria occurred singly within phagocytic vacuoles (Fig. 3). In contrast, when the bacteria were opsonized with patient's serum in the presence of $\mathrm{IgG}$, most polymorphonuclear leukocytes contained ingested bacteria, and two or more bacteria were routinely observed within phagocytic vacuoles in various stages of disintegration. These data visually documented the positive effect of anticapsular IgG on ingestion of the pneumococci.

Effect of anticapsular IgG and IgM during and after opsonization. To investigate the mode of enhancement of opsonization by anticapsular IgG and IgM, these preparations were added during opsonization of the bacteria with patients' sera or afterwards together with the polymorphonuclear leukocytes. The same amount of IgG or IgM was added under both sets of conditions. Addition of the immunoglobulin preparations during opsonization resulted in a marked enhancement of bacterial uptake and killing (Table I). In contrast, these preparations had no effect on uptake and killing if added after opsonization. These results indicated that both anticapsular IgG and IgM enhanced opsonization through a direct interaction with complement.

Effect of anticapsular IgG and IgM on C3 deposition. To

Table I. Effect of Anti-Type 10A IgG and IgM During and After Opsonization of the Pneumococci with Patients' Sera

\begin{tabular}{|c|c|c|c|c|c|}
\hline \multirow[b]{2}{*}{$\begin{array}{l}\text { Anticapsular } \\
\mathrm{Ig}^{*}\end{array}$} & \multirow{2}{*}{$\begin{array}{l}\text { Ig added during or } \\
\text { after opsonization }\end{array}$} & \multicolumn{2}{|c|}{ Patient $2^{\ddagger}$} & \multicolumn{2}{|c|}{ Patient $4^{\ddagger}$} \\
\hline & & Uptake & Killing & Uptake & Killing \\
\hline & & $\%$ & $\%$ & $\%$ & $\%$ \\
\hline \multirow[t]{2}{*}{ IgG } & During & $79 \pm 5$ & $77 \pm 14$ & $86 \pm 5$ & $94 \pm 1$ \\
\hline & After & $36 \pm 3$ & $7 \pm 7$ & $46 \pm 3$ & $0 \pm 0$ \\
\hline \multirow[t]{2}{*}{ IgM } & During & $97 \pm 2$ & $84 \pm 1$ & $92 \pm 8$ & $94 \pm 2$ \\
\hline & After & $36 \pm 1$ & $7 \pm 7$ & $40 \pm 4$ & $4 \pm 4$ \\
\hline None & & $39 \pm 1$ & $0 \pm 0$ & $50 \pm 2$ & $8 \pm 6$ \\
\hline
\end{tabular}

Data are expressed as mean \pm SEM of two to six determinations.

* Amount of anticapsular IgG or IgM added to the assays was $50 \mu \mathrm{g}$.

‡ Sera used for opsonization were from patients 2 and 4. 
determine if anticapsular IgG and IgM enhanced C3 deposition on the pneumococci, C3 deposition in patients' sera was measured before and after supplementation with increasing concentrations of the immunoglobulin preparations under the conditions used for opsonization. In support of our previous observations (14), normal numbers of $\mathrm{C} 3$ molecules were deposited on the pneumococci in the absence of added immunoglobulin, indicating that alternative pathway-mediated $\mathrm{C} 3$ deposition under these conditions occurred normally (Fig. 4). Anticapsular IgG and IgM enhanced C3 deposition in patients' sera to a supranormal level, and anticapsular IgG was more effective than anticapsular IgM. Similar increases in C3 deposition were observed when the immunoglobulin preparations were added to normal serum. Anticapsular IgG and IgM at a concentration of $50 \mu \mathrm{g}$ increased $\mathrm{C} 3$ deposition from $\sim 1.0 \times 10^{5} \mathrm{C} 3$ molecules/ cfu to $3.0 \times 10^{5}$ and $2.0 \times 10^{5} \mathrm{C} 3$ molecules/cfu, respectively.

Evidence that anticapsular antibodies mediated the enhancement of opsonization and $C 3$ deposition. Three pieces of evidence were obtained suggesting that anticapsular IgG and IgM antibodies mediated the enhancement of opsonization and C3 deposition observed in the preceding experiments. First, preliminary experiments demonstrated that heat-inactivated goat antiserum to capsular polysaccharide (the source of anticapsular IgG and IgM) markedly enhanced opsonization and C3 deposition in patients' sera, whereas heat-inactivated normal goat serum had less of an effect on these parameters. Secondly, binding studies with radioiodinated anticapsular IgG and IgM confirmed that these preparations contained antibodies reactive with serotype 10A (Fig. 5). Anticapsular IgG and IgM bound minimally to $S$. pneumoniae $\mathrm{R} 36 \mathrm{a}$, an unencapsulated strain, suggesting that the majority of antibodies in these preparations were directed against the capsular polysaccharide. Thirdly, adsorption of anticapsular IgG and IgM with serotype 10A S. pneumoniae rendered these preparations inactive with respect to restoring opsonization in patient's serum, whereas adsorption with $S$. pneumoniae $\mathrm{R} 36 \mathrm{a}$ had no effect on restoration of opsonization. The results obtained with anticapsular IgG are shown in Fig. 6; results with anticapsular IgM were similar (data not shown).

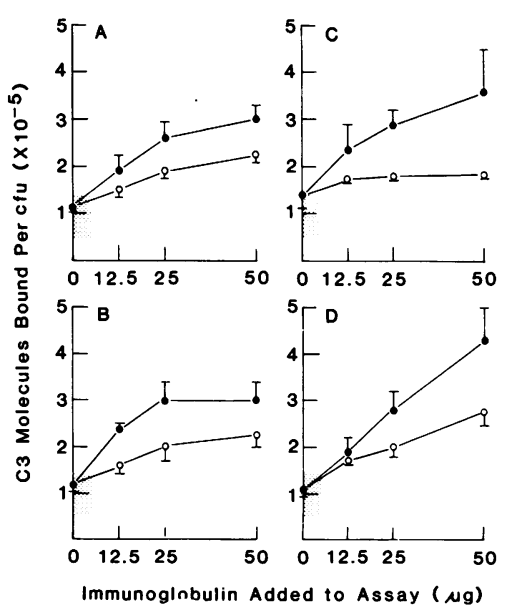

Figure 4. Effect of increasing concentrations of anticapsular IgG (closed circle) and IgM (open circle) on C3 deposition on pneumococci in patients' sera. $(A-D)$ show the data obtained with sera from patients $1-4$. These data are expressed as mean \pm SEM of two to four determinations. C3 deposition (mean $\pm 1 \mathrm{SD}$ ) in sera from 14 control subjects are shown in the shaded areas. These sera were not supplemented with purified immunoglobulins.

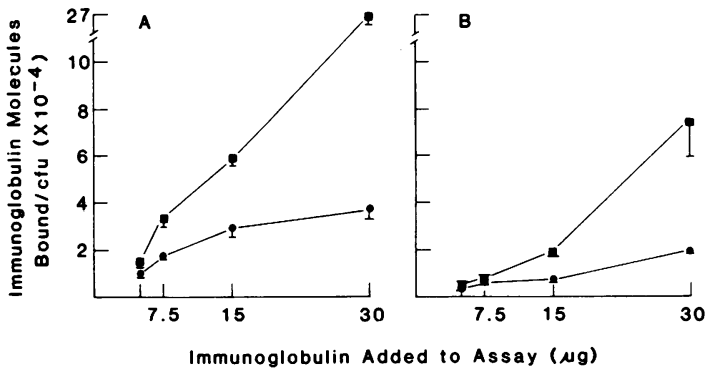

Figure 5. Binding of radioiodinated anticapsular IgG and IgM to serotype 10A $S$. pneumoniae (closed squares) and unencapsulated $S$. pneumoniae R36a (closed circles). ( $A$ ) Shows the data obtained with anticapsular IgG and $(B)$ the data with anticapsular IgM. Data are expressed as mean \pm SEM of two determinations.

Relationship between serum antibody titers to capsular polysaccharide and alternative pathway-mediated opsonization. Twenty nine patients with sickle cell disease and 14 normal controls were used in this part of our investigation. The patients were subdivided into a group of 13 with reduced alternative pathway-mediated opsonic activity for serotype 10A and a group of 16 with normal opsonic activity for this serotype (Table II). The first group included seven of the patients studied in the first part of our investigation. Subjects in the three groups were of similar age.

Serum IgG and IgM antibody titers to capsular polysaccharide in the two patient groups and controls were first compared. IgG anticapsular antibody titers were significantly reduced in sera from the first patient group (opsonically deficient) as compared with the second patient group (opsonically normal) and controls $(P<0.001$, Table II). Serum IgM anticapsular antibody titers were not significantly different in the three groups.

Correlations were assessed between IgG and IgM antibody titers to capsular polysaccharide and alternative pathway-mediated opsonic activity in patients' sera. IgG anticapsular antibody titers correlated significantly with measurements of uptake

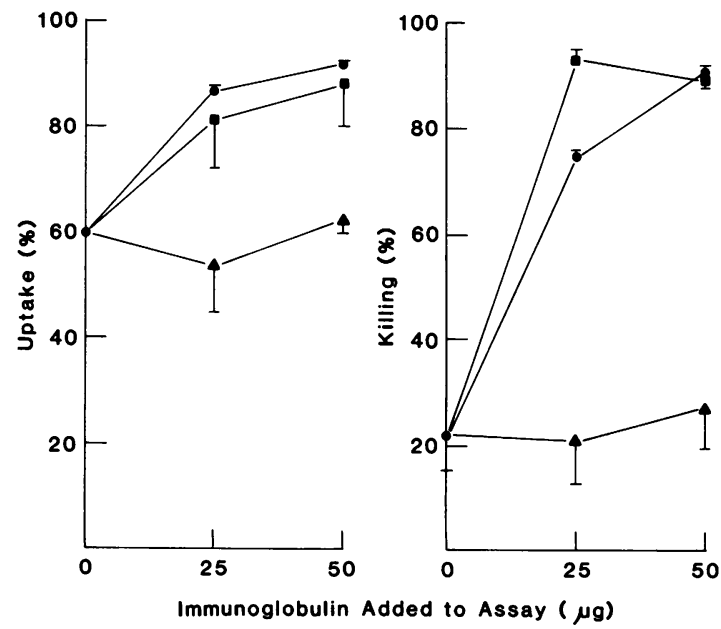

Figure 6. Specificity of opsonizing antibodies in anticapsular IgG. Anticapsular IgG was adsorbed with serotype 10A $S$. pneumoniae (closed triangle), S. pneumoniae R36a (closed squares), or was unadsorbed (closed circles). Serum from patient 6 was supplemented with adsorbed or unadsorbed IgG, and effects on uptake and killing of serotype $10 \mathrm{~A}$ by normal polymorphonuclear leukocytes were determined. Data are expressed as mean \pm SEM of two determinations. 
Table II. IgG and IgM Anti-Type 10A Antibody Titers in Sera from Patients with Sickle Cell Disease and Normal Controls

\begin{tabular}{|c|c|c|c|c|c|c|}
\hline \multirow[b]{2}{*}{ Subjects } & \multirow[b]{2}{*}{ Group } & \multirow{2}{*}{$\begin{array}{l}\text { Mean age } \\
\text { (range) }\end{array}$} & \multirow[b]{2}{*}{ Uptake* } & \multirow[b]{2}{*}{ Killing* } & \multicolumn{2}{|c|}{$\begin{array}{l}\text { Geometric mean } \\
\text { antibody titer (range) }\end{array}$} \\
\hline & & & & & IgG & IgM \\
\hline & & $y r$ & $\%$ & $\%$ & & \\
\hline $\begin{array}{l}\text { Patients } \\
\quad(n=13)\end{array}$ & 1 & $\begin{array}{l}7.4 \\
(2-15)\end{array}$ & $56 \pm 9$ & $15 \pm 12$ & $\begin{array}{l}97^{\ddagger} \\
(32-287)\end{array}$ & $\begin{array}{l}60 \\
(21-134)\end{array}$ \\
\hline$(n=16)$ & 2 & $\begin{array}{l}7.8 \\
(3-14)\end{array}$ & $80 \pm 10$ & $74 \pm 20$ & $\begin{array}{l}376 \\
(156-1451)\end{array}$ & $\begin{array}{l}94 \\
(9-284)\end{array}$ \\
\hline $\begin{array}{l}\text { Controls } \\
\qquad(n=14)\end{array}$ & & $\begin{array}{l}7.4 \\
(3-13)\end{array}$ & $75 \pm 11$ & $63 \pm 17$ & $\begin{array}{l}518 \\
(221-2,208)\end{array}$ & $\begin{array}{l}88 \\
(5-412)\end{array}$ \\
\hline
\end{tabular}

* Results are presented as mean \pm 1 SD.

${ }^{\ddagger} P<0.001$ as compared with group 2 and controls.

and killing $(P<0.005$, Fig. $7 A$ ). Correlations between IgM anticapsular antibody titers and these measurements approached statistical significance $(P>0.05<0.1$, Fig. $7 B$ ). The most significant correlations were between the sum of the IgG and IgM antibody titers and uptake and killing $(P<0.001$, Fig. $7 C)$. These results indicated that reduction in alternative pathwaymediated opsonization in the patients' sera was related to low levels of both IgG and IgM anticapsular antibodies.

IgG subclass-specific antibody titers to serotype $10 \mathrm{~A}$ capsular polysaccharide were also measured in sera from a subset of 20

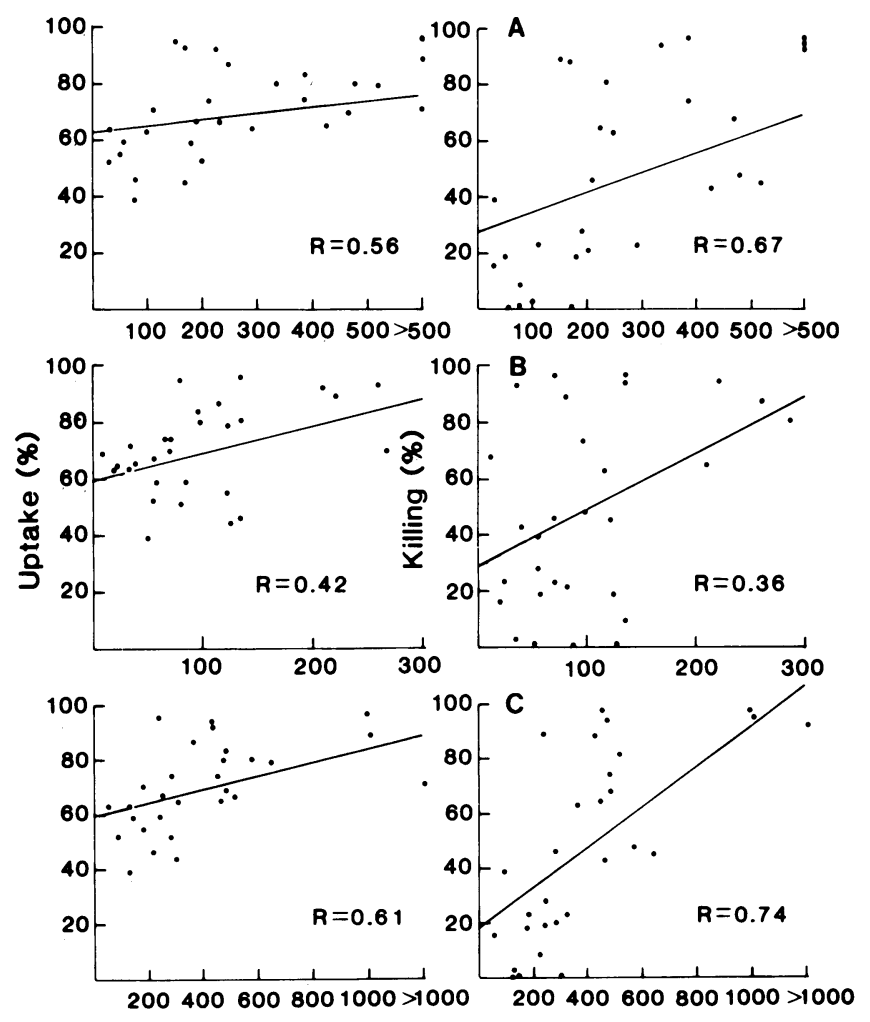

Antibody Titer

Figure 7. Relationships between bacterial uptake and killing and antitype $10 \mathrm{~A}$ antibody titers in patients' sera. $(A) \mathrm{IgG}$ antibody titers; $(B)$ IgM antibody titers; $(C)$ the sum of IgG and IgM antibody titers. children with sickle cell disease. 19 of these patients were the same as those analyzed in the preceding experiments. Normal controls were not included in this part of our study, because the quantities of sera on these subjects were insufficient to perform the analyses. Preliminary experiments confirmed the specificity of the monoclonal antibodies to IgG subclasses used in the IgG subclass-specific ELISAs. The lower limit of detection in these assays was $0.01 \mu \mathrm{g} / \mathrm{ml}$ of $\mathrm{IgG1}$ and $\mathrm{IgG} 3,0.1 \mu \mathrm{g} / \mathrm{ml}$ of $\mathrm{IgG} 2$, and $0.05 \mu \mathrm{g} / \mathrm{ml}$ of $\mathrm{IgG} 4$. Patients were again subdivided into two groups according to opsonic activity (Table III). Serum antibodies to capsular polysaccharide in both groups were predominantly of the IgG1 and IgG2 subclasses. The proportion of patients with positive IgG1 and IgG2 antibody titers was lower in group 1 (opsonically deficient) than in group 2 (opsonically normal). IgG2 antibody titers were significantly lower in group 1 than group $2(P=0.02)$. Analysis of the relationship between IgG subclass-specific antibody titers and bacterial uptake and killing revealed significant correlations between IgG1 and IgG2 antibody titers and killing $(P<0.007$, Fig. $8 A$ and $B)$. The most significant correlation was between the sum of the IgG1 and IgG2 antibody titers and killing $(P=0.001$, Fig. $8 C)$. Correlations were not significant in this patient group between IgG subclass-specific or total IgG antibody titers and bacterial uptake. These results indicated that antibodies of both the IgG1 and IgG2 subclasses in patients' sera contributed to alternative pathway-mediated opsonization.

\section{Discussion}

The results of our investigation provide direct evidence suggesting that reduction in serum opsonization of $S$. pneumoniae via the alternative complement pathway in children with sickle cell disease is related to a deficiency of antibodies to pneumococcal capsular polysaccharide. It was shown that purified IgG and IgM fractions of goat antiserum to capsular polysaccharide restored alternative pathway-mediated opsonization of $S$. pneumoniae in patients' sera to normal and lacked opsonic activity when tested alone. In addition, the sum of IgG and IgM antibody titers to capsular polysaccharide in patients' sera correlated significantly with alternative pathway-mediated opsonic activity. Separate analysis of the antibody data revealed that titers of IgG anticapsular antibodies correlated significantly with opsonic activity, whereas the correlation between opsonic activity and titers of IgM anticapsular antibodies approached statistical significance.

Table III. IgG Subclass-specific Anti-Type 10A Antibody Titers in Sera from Patients with Normal and Decreased Opsonic Activity

\begin{tabular}{lllllllll}
\hline & & & & \multicolumn{5}{l}{$\begin{array}{l}\text { Proportion of patients } \\
\text { with positive antibody titers } \\
\text { (range of positive antibody titers) }\end{array}$} \\
\cline { 5 - 9 } $\begin{array}{l}\text { Patient } \\
\text { group }\end{array}$ & $\begin{array}{l}\text { Mean age } \\
\text { (range) }\end{array}$ & Uptake* & Killing* & IgG1 & IgG2 & IgG3 & IgG4 \\
\hline & $y r$ & $\%$ & $\%$ & & & & \\
1 & 8.1 & $59 \pm 14$ & $20 \pm 16$ & $3 / 8$ & $4 / 8$ & $1 / 8$ & $0 / 8$ \\
$(n=8)$ & $(3-15)$ & & & $(5-27)$ & $(5-32)$ & $(9)$ & \\
2 & 8.7 & $78 \pm 9$ & $69 \pm 22$ & $9 / 12$ & $11 / 12$ & $4 / 12$ & $1 / 12$ \\
$(n=12)$ & $(3-12)$ & & & $(6-69)$ & $(6-424)$ & $(6-81)$ & $(16)$
\end{tabular}

* Results are presented as mean \pm 1 SD. 


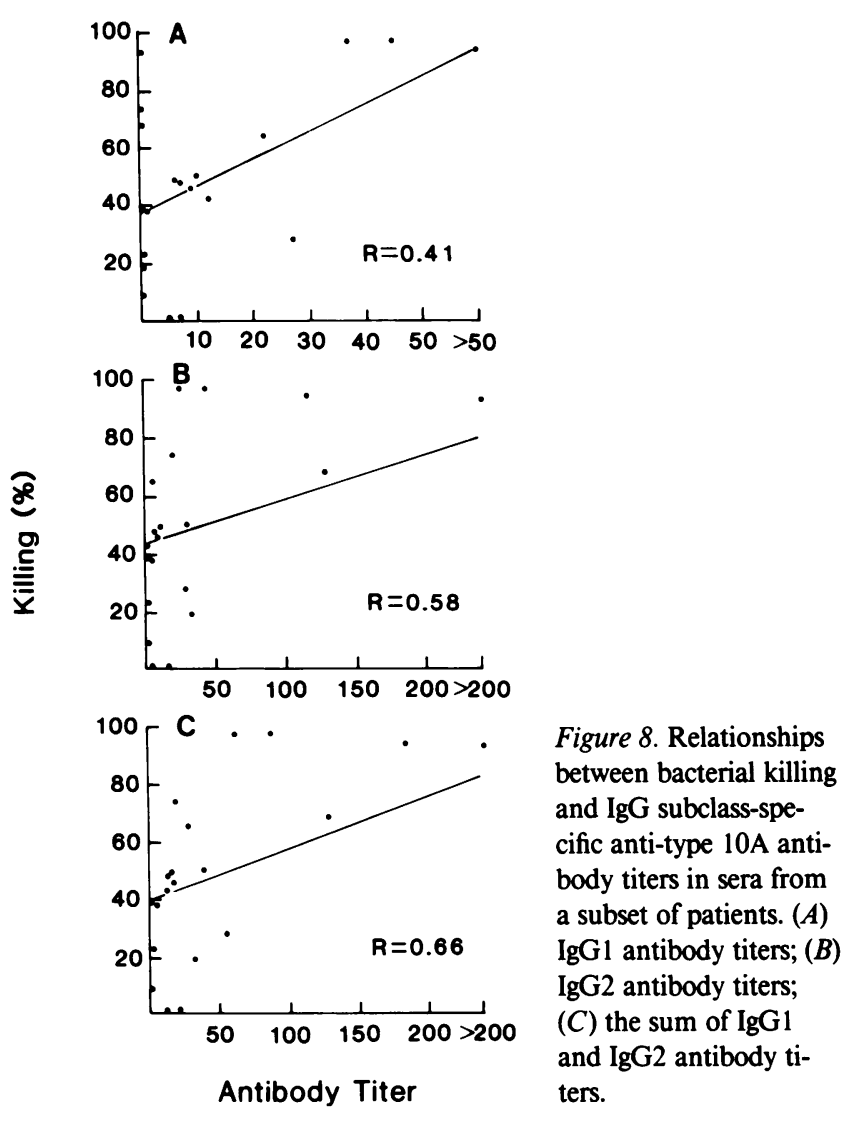

These observations suggest that the levels of both IgG and IgM anticapsular antibodies influenced alternative pathway-mediated opsonization in patients' sera and that the greatest influence was exerted by antibodies of the IgG class.

IgG antibodies to capsular polysaccharide in patients' sera were shown to be predominantly of the IgG1 and IgG2 subclasses. Correlative analyses suggested that antibodies of both of these subclasses contributed to opsonization. Previous studies have shown that immunization of normal adults with pneumococcal capsular polysaccharides elicits antibodies primarily of the IgG2 subclass $(35,36)$. IgG subclass-specific antibody responses to pneumococcal polysaccharides in normal children have not yet been reported.

The serotype 10A pneumococcal test organism used in our study was a serotype not contained in the 14-valent pneumococcal polysaccharide vaccine that all of the children with sickle cell disease on our study received as a part of routine care. By selecting a serotype to which the children had not been immunized, antibodies formed by natural exposure to pneumococci could be assessed. The presence of high anticapsular antibody titers in sera from normal children and opsonically normal children with sickle cell disease confirmed exposure to serotype 10A in both populations. Serotype $10 \mathrm{~A}$ is contained in the 23 -valent pneumococcal polysaccharide vaccine in current use, but none of the children with sickle cell disease on our study received this vaccine before serum was collected. The serotype $10 \mathrm{~A}$ test strain was originally isolated from the blood culture of a child with sickle cell disease, and results obtained with this strain should be able to be extrapolated to other pneumococcal serotypes of similar virulence.

Preliminary information was obtained in our investigation regarding the mode of enhancement of alternative pathway-me- diated opsonization in patients' sera by purified anticapsular IgG and IgM. Both immunoglobulin preparations enhanced bacterial uptake and killing by polymorphonuclear leukocytes only if present during opsonization with patient's serum and not if added together with the leukocytes after opsonization. This observation suggests that the immunoglobulin preparations exerted their effect through a direct interaction with complement rather than the leukocytes. Anticapsular IgG and IgM quantitatively enhanced $\mathrm{C} 3$ deposition on the pneumococci to a supranormal level, and the effect was greater with anticapsular IgG than IgM. In studies from our laboratory reported in a separate communication (37), we have shown that removal of the $\mathrm{Fc}$ fragment of anticapsular IgG by pepsin digestion did not alter its ability to enhance opsonization and $\mathrm{C} 3$ deposition in patients' sera, suggesting that the $F\left(a b^{\prime}\right)_{2}$ region mediated these events.

The demonstration that anticapsular IgG and to a lesser extent IgM increased C3 deposition in patients' sera to a supranormal level suggests that augmentation of the assembly of alternative pathway $\mathrm{C} 3$ convertase on the bacterial surface may be one of the mechanisms involved in the enhancement of opsonization. Winkelstein et al. (38) originally reported that normal guinea pig IgG augmented $\mathrm{C} 3$ consumption by $S$. pneumoniae via the alternative complement pathway. Edwards et al. (39) demonstrated that IgG antibodies directed against the capsular polysaccharide of type III, group B streptococci enabled this bacterium to activate the alternative pathway. In a number of nonbacterial systems, IgG antibodies have been shown to augment alternative pathway activation by activators and to convert nonactivators of the alternative pathway to activators (17). In these latter studies, a major effect of IgG was to increase C3 deposition via the alternative pathway on the test activators.

Minimal information is available concerning interactions between antibodies of the IgM class and the alternative complement pathway. Okada et al. (40) reported that natural IgM antibodies participated in alternative pathway-mediated lysis of liposomes containing paragloboside in their membranes. IgM has been shown to bind C3b to a greater extent than $\operatorname{IgG}(41)$, and a recent study suggests that anti-pneumococcal antibodies of both the IgG and IgM classes bind C3b covalently (42). Through their interaction with $\mathrm{C} 3 \mathrm{~b}$, antibodies to the pneumococcal capsular polysaccharide may redirect alternative pathway activation and further $\mathrm{C} 3 \mathrm{~b}$ deposition from the area of the bacterial cell wall to the capsule and thereby enhance bacterial phagocytosis $(43,44)$.

In our study, anticapsular IgG and IgM appeared to primarily affect the internalization phase of phagocytosis. Experiments in which phagocytosis was inhibited by treatment of polymorphonuclear leukocytes with cytochalasin B suggested that patients' sera facilitated adherence but not ingestion and killing of the pneumococci in the absence of added immunoglobulin. Addition of anticapsular IgG or IgM to patients' sera increased bacterial uptake and killing by the leukocytes. Since adherence was near normal or in the low normal range in the absence of added immunoglobulin, the major effect of anticapsular IgG and IgM appeared to be in triggering phagocytosis, which was necessary for killing. Further support for this concept was derived from electron microscopic studies comparing ingestion of bacteria opsonized with patient's serum .with and without added anticapsular IgG. Anticapsular IgG and IgM may also directly affect the intracellular killing process, although this was not established in our study.

Synergism between antibodies and complement in the in- 
duction of phagocytosis was originally described by Ward and Enders in 1933 (45). Studies by Johnston et al. (46) demonstrated that the sequential addition of purified classical complement pathway components to antibody-sensitized pneumococci enhanced phagocytosis by polymorphonuclear leukocytes. Little is known about synergistic interactions between antibody and the alternative complement pathway in bacterial phagocytosis or about the specific functions of antibody and complement in this process. Studies on the relative roles of $\mathrm{IgG}$ and $\mathrm{C} 3 \mathrm{~b}$ in facilitating phagocytosis of erythrocytes by polymorphonuclear leukocytes have shown that $\mathrm{C} 3 \mathrm{~b}$ promotes adherence, and IgG mediates ingestion $(15,16)$. Very high concentrations of $\mathrm{IgG}$ promote both adherence and ingestion in the absence of $\mathrm{C} 3 \mathrm{~b}$ through interaction with $\mathrm{Fc}$ receptors on the polymorphonuclear leukocytes $(15,16)$. The Fc receptors on polymorphonuclear leukocytes recognize all subclasses of $\mathrm{IgG}$, although it is not known whether all subclasses induce ingestion (47-49). IgM is not recognized by the Fc receptors on either cell type, and IgM does not act together with $\mathrm{C} 3 \mathrm{~b}$ to facilitate ingestion of erythrocytes by these cells $(15,16)$.

The relative contributions of antibodies and $\mathrm{C} 3 \mathrm{~b}$ to bacterial phagocytosis are not well understood, because there have been few studies in which purified proteins have been used. C3b on certain bacterial strains appears to be capable of promoting phagocytosis in the absence of antibodies, whereas phagocytosis of other strains appears to be dependent on both antibodies and complement (50-52). Both IgG and IgM antibacterial antibodies have been shown to act synergistically with complement in the induction of phagocytosis, although the mechanisms involved have not been explored (50). These observations and those of our investigation suggest that IgM antibodies like those of the IgG class play an important role in the induction of bacterial phagocytosis by polymorphonuclear leukocytes, and both classes of antibodies exert their effect without involvement of the Fc receptor.

Relationships between serum opsonization of $S$. pneumoniae and titers of IgG and IgM anticapsular antibodies in children with sickle cell disease have not been previously investigated. Class-specific antibody responses to the pneumococcal polysaccharide vaccine have been compared in children with sickle cell disease and normal children of similar age (53). The level and predominant class of antibody were shown to vary with the serotype of antigen tested. Although statistically significant differences were not found, lower responses were noted in the children with sickle cell disease than in the controls. Serum opsonic activity was not measured in this study. Chudwin et al. (54) have recently investigated the relationship between serum opsonic activity for serotype 7F S. pneumoniae and total antibodies to serotype 7F capsular polysaccharide measured by radioimmunoassay in children with sickle cell disease following immunization with pneumococcal polysaccharide vaccine. A significant correlation between these measurements was observed, and patients were identified whose opsonic and total antibody responses to vaccination were poor. It is probable that these patients represent a subset similar to those identified in our study who respond poorly to natural exposure to $S$. pneumoniae.

Mechanisms underlying the depression in humoral immunity to pneumococcal capsular polysaccharide in certain children with sickle cell disease are currently unknown. Splenic hypofunction may contribute to the altered state of immunity, since a similar condition, splenectomy, has been associated with depressed immune responses to pneumococcal polysaccharide vaccine $(19$,
55-58) and diminished secretion of immunoglobulins by peripheral blood mononuclear cells in response to stimulation with pokeweed mitogen (59-63). The role of genotypic variation in patients with sickle cell disease also requires exploration in light of a recent report demonstrating a relationship between immunoglobulin allotypes and the immune response to pneumococcal capsular polysaccharides in normal subjects (64).

\section{Acknowledgments}

We thank Dr. Muhammad Ashraf for performing the electron microscopic studies, Dr. Douglas Barrett for helpful discussions regarding the ELISA methodology, Dr. Robert Schreiber for the gift of antiserum to human IgG, Dr. Robert Facklam for subtyping the pneumococcal test strain, and Patricia Magnafichi, Kathy Price, and Marcia Bacon for excellent technical assistance.

This work was supported by research grant HL-31165 and center grant HL-15966 from the National Heart, Lung, and Blood Institute.

\section{References}

1. Barrett-Connor, E. 1971. Bacterial infection and sickle cell anemia. Medicine. 50:97-112.

2. Overturf, G. D., D. Powars, and L. J. Baraff. 1977. Bacterial meningitis and septicemia in sickle cell disease. Am. J. Dis. Child. 131:784 787.

3. Powars, D., G. Overturf, J. Weiss, S. Lee, and L. Chan. 1981 Pneumococcal septicemia in children with sickle cell anemia. J. Am. Med. Assoc. 245:1839-1842.

4. Pearson, H. A., R. P. Spencer, and E. A. Cornelius. 1969. Functional asplenia in sickle-cell anemia. N. Engl. J. Med. 281:923-926.

5. Rogers, D. W., S. Vaidya, and G. R. Serjeant. 1978. Early splenomegaly in homozygous sickle-cell disease: an indicator of susceptibility to infection. Lancet. ii:963-965.

6. Rogers, D. W., B. E. Serjeant, and G. R. Serjeant. 1982. Early rise in 'pitted' red cell count as a guide to susceptibility to infection in childhood sickle cell anaemia. Arch. Dis. Child. 57:338-342.

7. Winkelstein, J. A., and R. H. Drachman. 1966. Deficiency of pneumococcal serum opsonizing activity in sickle-cell disease. $N$. Engl. J. Med. 279:459-466.

8. Johnston, R. B., Jr., S. L. Newman, and A. G. Struth. 1973. An abnormality of the alternate pathway of complement activation in sicklecell disease. N. Engl. J. Med. 288:803-808.

9. Bjornson, A. B., M. H. Gaston, and C. L. Zellner. 1977. Decreased opsonization for Streptococcus pneumoniae in sickle cell disease: Studies on selected complement components and immunoglobulins. J. Pediatr. 91:371-378.

10. Bjornson, A. B., J. S. Lobel, and B. C. Lampkin. 1980. Humoral components of host defense in sickle cell disease during painful crisis and asymptomatic periods. J. Pediatr. 96:259-262.

11. Hernandez, D. E., N. Gonzalez, R. Rios, L. Merchan, and H. Wuani. 1983. Phagocytosis in patients with sickle cell disease. J. Clin. Lab. Immunol. 12:137-140.

12. Luo, N. K., and H. A. K. Rowland. 1983. The bactericidal and opsonic effects of serum from patients with sickle cell anaemia. Bull. Soc. Pathol. Exot. 76:657-667.

13. Bloch, E. F., O. Castro, J. E. Gregory, and C. Okoh. 1984. Opsonization of pneumococci by whole serum from sickle cell disease patients. J. Natl. Med. Assoc. 76:179-182.

14. Bjornson, A. B., J. S. Lobel, and K. S. Harr. 1985. Relation between serum opsonic activity for Streptococcus pneumoniae and complement function in sickle cell disease. J. Infect. Dis. 152:701-709.

15. Ehlenberger, A. G., and V. Nussenzweig. 1977. The role of membrane receptors for C3b and C3d in phagocytosis. J. Exp. Med. 145: 357-371.

16. Newman, S. L., and R. B. Johnston, Jr. 1979. Role of binding 
through $\mathrm{C} 3 \mathrm{~b}$ and IgG in polymorphonuclear neutrophil function: studies with trypsin-generated C3b. J. Immunol. 123:1839-1846.

17. Ratnoff, W. D., D. T. Fearon, and K. F. Austen. 1983. The role of antibody in the activation of the alternative complement pathway. Springer Semin. Immunopathol. 6:361-371.

18. Bjornson, A. B., J. S. Lobel, P. I. Magnafichi, and B. C. Lampkin. 1981. Restoration by normal human immunoglobulin $\mathrm{G}$ of deficient serum opsonization for Streptococcus pneumoniae in sickle cell disease. Infect. Immun. 33:636-640.

19. Hosea, S. W., C. G. Burch, E. J. Brown, R. A. Berg, and M. M. Frank. 1981. Impaired immune response of splenectomized patients to polyvalent pneumococcal vaccine. Lancet. i:804-807.

20. Barrett, D. J., C. G. Lee, A. J. Ammann, and E. M. Ayoub. 1984. IgG and IgM pneumococcal polysaccharide antibody responses in infants. Pediatr. Res. 18:1067-1071.

21. Cripps, A. W., S. H. Neoh, and I. J. Smart. 1983. Isolation of human IgA and IgM from normal serum using polyethylene glycol precipitation and affinity chromatography. J. Immunol. Methods 57:197204.

22. March, S. C., I. Parikh, and P. Cuatrecasas. 1974. A simplified method for cyanogen bromide activation of agarose for affinity chromatography. Anal. Biochem. 60:149-152.

23. Deutsch, H. F. 1967. Preparation of immunoglobulin concentrates. In Methods in Immunology and Immunochemistry. Vol. 1. C. A. Williams and M. W. Chase, editors. Academic Press, Inc., New York. 319.

24. Fahey, J. L. 1967. Chromatographic separation of immunoglobulins. In Methods in Immunology and Immunochemistry. Vol. 1. C. A. Williams and M. W. Chase, editors. Academic Press, Inc., New York. 321-324.

25. Tack, B. F., R. A. Harrison, J. Janatova, M. L. Thomas, and J. W. Prahl. 1980. Evidence for presence of an internal thiolester bond in third component of human complement. Proc. Natl. Acad. Sci. USA. 77:5764-5768.

26. Lowry, O. H., N. J. Rosebrough, A. L. Farr, and R. J. Randall. 1951. Protein measurement with the Folin phenol reagent. J. Biol. Chem. 193: $265-275$.

27. Laemmli, U. K. 1970. Cleavage of structural proteins during the assembly of the head of bacteriophage T4. Nature (Lond.). 227:680-685.

28. Ferrante, A., and Y. H. Thong. 1982. Separation of mononuclear and polymorphonuclear leucocytes from human blood by the one-step Hypaque-Ficoll method is dependent on blood column height. J. Immunol. Methods. 48:81-85.

29. Mayer, M. M. 1961. Complement and complement fixation. In Experimental Immunochemistry, 2nd edition. E. H. Kabat and M. M. Mayer, editors. Charles C Thomas, Springfield. 149-153.

30. Fearon, D. T., I. Kaneko, and G. G. Thomson. 1981. Membrane distribution and adsorptive endocytosis by $\mathrm{C} 3 \mathrm{~b}$ receptors on human polymorphonuclear leukocytes. J. Exp. Med. 153:1615-1628.

31. Vroon, D. H., D. R. Schultz, and R. M. Zarco. 1970. The separation of nine components and two inactivators of components of complement in human serum. Immunochemistry. 7:43-61.

32. Barrett, D. J., A. J. Ammann, S. Stenmark, and D. W. Wara. 1980. Immunoglobulin $G$ and $M$ antibodies to pneumococcal polysaccharides detected by enzyme-linked immunosorbent assay. Infect. Immun. 27:411-417.

33. Gray, B. M. 1979. ELISA methodology for polysaccharide antigens: Protein coupling of polysaccharides for adsorption to plastic tubes. J. Immunol. Methods. 28:187-192.

34. Snedecor, G. W. 1956. Statistical Methods. 5th ed. The Iowa State College Press, Ames. 115-117, 190-192.

35. Siber, G. R., P. H. Schur, A. C. Aisenberg, S. A. Weitzman, and G. Schiffman. 1980. Correlation between serum IgG-2 concentrations and the antibody response to bacterial polysaccharide antigens. $N$. Engl. J. Med. 303:178-182.

36. Barrett, D. J., and E. M. Ayoub. 1986. IgG2 subclass restriction of antibody to pneumococcal polysaccharides. Clin. Exp. Immunol. 63: 127-134.
37. Bjornson, A. B., and J. S. Lobel. 1986. Lack of a requirement for the $\mathrm{Fc}$ region of $\mathrm{IgG}$ in restoring pneumococcal opsonization via the alternative complement pathway in sickle cell disease. J. Infect. Dis. 154: 760-769.

38. Winkelstein, J. A., and H. S. Shin. 1974. The role of immunoglobulin in the interaction of pneumococci and the properdin pathway. Evidence for its specificity and lack of requirement for the Fc portion of the molecule. J. Immunol. 112:1635-1642.

39. Edwards, M. S., A. Nicholson-Weller, C. J. Baker, and D. L. Kasper. 1980. The role of specific antibody in alternative complement pathway-mediated opsonophagocytosis of type III, group B Streptococcus. J. Exp. Med. 151:1275-1287.

40. Okada, H., N. Okada, and T. Yasuda. 1983. Activation of the alternative complement pathway by IgM antibody reacted on paragloboside incorporated into liposome membrane. Mol. Immunol. 20:499_ 500.

41. Capel, P. J. A., O. Groeneboer, G. Grosveld, and K. W. Pondman. 1978. The binding of activated $C 3$ to polysaccharides and immunoglobulins. J. Immunol. 121:2566-2572.

42. Brown, E. J., M. Berger, K. A. Joiner, and M. M. Frank. 1983. Classical complement pathway activation by antipneumococcal antibodies leads to covalent binding of $\mathrm{C} 3 \mathrm{~b}$ to antibody molecules. Infect. Immun. 42:594-598.

43. Brown, E. J., S. W. Hosea, C. H. Hammer, C. C. Burch, and M. M. Frank. 1982. A quantitative analysis of the interactions of antipneumococcal antibody and complement in experimental pneumococcal bacteremia. J. Clin. Invest. 69:85-98.

44. Brown, E. J., K. A. Joiner, R. M. Cole, and M. Berger. 1983. Localization of complement component 3 on Streptococcus pneumoniae. Anticapsular antibody causes complement deposition on the pneumococcal capsule. Infect. Immun. 39:403-409.

45. Ward, H. K., and J. F. Enders. 1933. An analysis of the opsonic and tropic action of normal and immune sera based on experiments with the pneumococcus. J. Exp. Med. 57:527-547.

46. Johnston, R. B., Jr., M. R. Klemperer, C. A. Alper, and F. S. Rosen. 1969. The enhancement of bacterial phagocytosis by serum. The role of complement components and two cofactors. J. Exp. Med. 129: 1275-1290.

47. Henson, P. M., H. B. Johnson, and H. L. Spiegelberg. 1972. The release of granule enzymes from human neutrophils stimulated by aggregated immunoglobulins of different classes and subclasses. J. Immunol. 109:1182-1192.

48. Lawrence, D. A., W. O. Weigle, and H. L. Spiegelberg. 1975. Immunoglobulins cytophilic for human lymphocytes, monocytes, and neutrophils. J. Clin. Invest. 55:368-376.

49. Walsh, G. M., and A. B. Kay. 1986. Binding of immunoglobulin classes and subclasses to human neutrophils and eosinophils. Clin. Exp. Immunol. 63:466-472.

50. Horwitz, M. A. 1980. The roles of the Fc and C3 receptors in the phagocytosis and killing of bacteria by human phagocytes. J. Reticuloendothel. Soc. 28:17S-26S.

51. Leist-Welsh, P., and A. B. Bjornson. 1982. Immunoglobulinindependent utilization of the classical complement pathway in opsonophagocytosis of Escherichia coli by human peripheral leukocytes. J. Immunol. 128:2643-2651.

52. Schreiber, R. D., M. K. Pangburn, A. B. Bjornson, M. A. Brothers, and H. J. Muller-Eberhard. 1982. The role of C3 fragments in endocytosis and extracellular cytotoxic reactions by polymorphonuclear leukocytes. Clin. Immunol. Immunopathol. 23:335-357.

53. Barrett, D. J., and A. J. Ammann. 1981. Pneumococcal vaccine in sickle cell disease: IgG and IgM antibody response. Rev. Infect. Dis. 3:S179-S182.

54. Chudwin, D. S., S. G. Artrip, A. Korenblit, G. Schiffman, and S. Rao. 1985. Correlation of serum opsonins with in vitro phagocytosis of Streptococcus pneumoniae. Infect. Immun. 50:213-217.

55. Giebink, G. S., J. E. Foker, Y. Kim, and G. Schiffman. 1980. Serum antibody and opsonic responses to vaccination with pneumococcal 
capsular polysaccharide in normal and splenectomized children. J. Infect. Dis. 141:404-412.

56. Pedersen, F. K., J. Henrichsen, and G. Schiffman. 1982. Antibody response to vaccination with pneumococcal capsular polysaccharides in splenectomized children. Acta Paediatr. Scand. 71:451-455.

57. Giebink, G. S., C. T. Le, and G. Schiffman. 1984. Decline of serum antibody in splenectomized children after vaccination with pneumococcal capsular polysaccharides. J. Pediatr. 105:576-582.

58. Aaberge, I. S., H. E. Heier, E. Hem, K.-E. Giercksky, and E.-C. Groeng. 1984. IgM and IgG response to pneumococcal polysaccharide vaccine in normal individuals and individuals splenectomized due to trauma. Acta Pathol. Microbiol. Immunol. Scand. 92:11-16.

59. Di Padova, F., M. Durig, J. Wadstrom, and F. Harder. 1983. Role of spleen in immune response to polyvalent pneumococcal vaccine. Br. Med. J. 287:1829-1832.

60. Nielsen, J. L., P. Tauris, H. E. Johnsen, and J. Ellegaard. 1983. The cellular immune response after splenectomy in humans. Impaired immunoglobulin synthesis in vitro. Scand. J. Haematol. 31:85-95.
61. Drew, P. A., G. K. Kiroff, A. Ferrante, and R. C. Cohen. 1984. Alterations in immunoglobulin synthesis by peripheral blood mononuclear cells from splenectomized patients with and without splenic regrowth. J. Immunol. 132:191-196.

62. Muller, Ch., J. W. Mannhalter, R. Ahmad, G. Zlabinger, P. Wurnig, and M. M. Eibl. 1984. Peripheral blood mononuclear cells of splenectomized patients are unable to differentiate into immunoglobulinsecreting cells after pokeweed mitogen stimulation. Clin. Immunol. Immunopathol. 31:118-123.

63. Sieber, G., H.-G. Breyer, F. Herrmann, and H. Ruhl. 1985. Abnormalities of B-cell activation and immunoregulation in splenectomized patients. Immunobiology. 169:263-271.

64. Ambrosino, D. M., G. Schiffman, E. C. Gotschlich, P. H. Schur, G. A. Rosenberg, G. G. DeLange, E. van Loghem, and G. R. Siber. 1985. Correlation between $\mathrm{G} 2 \mathrm{~m}(\mathrm{n})$ immunoglobulin allotype and human antibody response and susceptibility to polysaccharide encapsulated bacteria. J. Clin. Invest. 75:1935-1942. 